\title{
An Empirical Study on Loan Concentration and Business Performance-Case of 3D1S Industries in Taiwan
}

\author{
Miin-Yu Peng ${ }^{1}$
}

Ph.D. student of department of Economics, SooChow University, Taiwan.

\begin{abstract}
The paper first analyze the loan concentration of Taiwan indus tries between year 1990 to 2014 . The high five industries are orderly as finance, shipping, touris $\mathrm{m}$, semi-conductive and steel, respectively. However, DRAM, LED, LCD and Solar are the four supporting industries in Taiwan. Yet, they were in financial crisis through the change of domestic and foreign economic environment. The government try to rescue these industries, it will lead to the high loan concentration. Not only affect the business performance, but also increase the non-performing loans. In empirical study, the paper apply panel data regression model with fixed effect to discuss the relationship of loan concentration on return of asset(ROA). The results show that the coefficient of loan concentration is negative. Which implies that the high loan concentration will decrease the ROA of industries and banking.
\end{abstract}

Keywords : Loan concentration, Business performance, Panel Data Regression model

Jel Classification: C13,C33, F10

\section{INTRODUCTION}

In 2010, the banks of Taiwan showed significant growth in lending with loan quality in good standing. Yet, the problem of credit risk concentration is still unresolved and loans tended to be skewed at specific industries. Indeed, market risk is fermenting. The global economy has been significantly affected by the financial crisis and the sovereign debt crisis in Europe and America that turned their economies stagnant or downward. The problem is manifested in the bubble effect of the real estate industry and the excessive production capacity of the electronics industry in Taiwan. Specific industries, including communications and electronics, remained the primary source of export trade in Taiwan. These industries have already closely associated with the economy of Taiwan, particularly the strategic industries under government support, like the DRAM and LED. In addition, the information and electronics industries of the region have resorted to the research and development of the foresight industries of LED (energy efficiency and for lighting) and photovoltaic energy (PV, green energy) for industrial transformation. However, these four major industries (hereinafter, "3D1S") have excessive production capacity worldwide and cut-throat competition, which contributed to the surfacing of an imminent crisis.

Irrespective of this situation, the government of Taiwan made public-owned banks and financial institutions offer financial relief to these industries, to the effect that banks in the region have high concentration s of loans at specific industries, which has been demonstrated in the financial crisis of 2008 to its entirety. DRAM firms like Powerchip Technology Corp. and ProMOS Technologies have borrowed more than NT $\$ 400$ billion from banks in Taiwan. It was even so in early 2009 that the DRAM sector was at the brink of collapse. At this juncture, should we worry about the excessive concentration of loans from banks to specific industries and the upward movement of non-performing ratios? Furthermore, what kind of impact will there be when banks exhibit different levels of concentrations of loans to different industries on the operational performance of these industries? Loan concentration could be generally defined as the concentration of loans to particular groups of customers shall not

${ }^{1}$ Corresponding Author: monicapeng30@yahoo.com.tw 
exceed $15 \%$ of the total loans to net worth ratio of the principal group customer. This indicator is a level I indicator, including one Level II indictor of loan concentration of particular customers. Loan concentration of a particular customer shall not exceed $10 \%$ of the total loan to net worth ratio of the principal customer. The following equation explains loan concentration in general:

Loan concentration of particular group customer=Total loans of the prin cipal group customer/ net worth x 100\%

Banks will be vulnerable to the extre mely high credit risk at the time of global economic downturn and the profit of the industries with high concentrations of loans from the banks is in danger if they have an excessive contraction of loans in these industries.

Under the constraint of data availability, the loan concentration of individual industries is defined as:

Long-term and short-term loan of specific industry/Long-term and short-term loan of the industrial sector

Among the literature on loan concentration, Lee (2010) explored the changes in loan concentrations of banks engaging in syndicated loans during the financial crisis in an essay. Chuang (2004) sought to assess the relation ship between the performance of banks and loan concentration from the perspective of loan concentration. Chen (2007) constructed an indicator system for detecting industry risk and a PCA-logit model, and a model for control limit by industry. These could be served as reference for the control of loan concentration. Dullmann and Masschelein (2006) assessed the loan of banks to the industrial sector and economic capital loan concentration with the multifactor model. Jahn et al. (2013) probed the cred it risk deriving from the loans of the banking sector in Germany to specific industries and the impact that caused. However, findings from empirical studies indicated that the industries managed under loan portfolios have lower levels of losses after being monitored. Tabak et al. (2010) took the bank financing of Brazil as a case study to assess the diversity of the loan portfolios of banks. He also assessed the relationship between loan concentration of banks and risks and returns. The findings from the empirical study indicated that high concentrations of loans tended to enhance the business performance and reduce default risk of the lending banks. Likewise, he also discovered loan concentration is on the rise after the financial crisis.

Also, panel data have been extensively used in the research of finance and banking. These data not only could serve as informative data, but also significantly enhanced the degree of freedom that made estimation more efficient. At the same time, it allows the researchers to construct and test more complex behavioral models. There is a large amount of literature in this field: Henderson and Kaplan (2000), Altunbas et al.(2002), and Ayuso et al. (2004). As such, this paper is subject to the verification of the panel data regression analysis model. The integration of time series data and cross sectional data allows for chronological dynamics and also comprises the heterogeneity of data cross the same point of time, which gave a fuller picture of complete data than the traditional data. In consideration of the aforementioned literature in the application of panel data in the regression analysis of the finance and banking sector and also the specific nature of the data, the panel data regression model is adopted in this study for empirical analysis.

In an empirical study, this paper provides an analysis of loan concentrations of banks to different industries with the industries that absorbed a high loan concentration from banks of Taiwan in particular. They are the four strategic industries of DRAM, LCD, LED, and photovoltaic energy. The data covers the period of 1990 to 2014, a total of 25 years. Further to the concentration of loan to the industries, this paper also attempts to explore the effect of loan concentration of the banks in Taiwan to the four strategic industries to their revenues and also the very nature of the capital structures of these banks.

\section{THE EMPIRICALMODEL}

Traditionally, the method of ord inary least squares, or OLS, was adopted to analyze panel data under the assumption that the parameters remain constant. This practice can easily cause the problem of heterogeneity bias. Under the 
panel data regression model, both time series and cross sectional data are integrated in the model for analysis. This helps to control the individual variations of cross sectional data and the autocorrelation of time series data and get a more efficient estimation result and solve the problem of estimate bias. The fundamental equation of the panel data regression model is shown below:

Where,

$$
Y_{i t}=\alpha_{1 i}+\sum_{K=2}^{K} \beta_{k} X_{k i t}+\varepsilon_{i t}
$$

$\mathrm{i}:$ different industries, and $\mathrm{i}=1 \ldots \mathrm{N}$;

$\mathrm{t}:$ sample observation time, and $\mathrm{t}=1 \ldots \mathrm{T}$;

$\mathrm{k}$ : explained variable, and $\mathrm{k}=1 \ldots \mathrm{K}$;

$Y_{i t}$ : the vector of the $\mathrm{i}^{\text {th }}$ observation unit in the $\mathrm{t}^{\text {th }}$ period, and is the explained variable;

$\beta_{k}$ : the coefficient of the explained variable in the equation;

$X_{i t}$ : the vector of the $\mathrm{k}^{\text {th }}$ explained variable of the $\mathrm{i}^{\text {th }}$ observation unit in the $\mathrm{t}^{\text {th }}$ period;

$\alpha_{1 i}$ : the intercept, and is individual effect irrespective of the change over time. Individual effect varies with different observation units;

In consideration of the variance of the intercept assumption, the pooled regression model, fixed

effect model, and random effect model of the panel data regression model is adopted in this study for empirical analysis in order to sort out the optimal choice.

For determination of the applicability of sample data and the OLS, fixed effect model or random effect model, the F-test of Greene (2003), the Lagrange Multip lier (LM) of Breusch and Pagan (1980), and the Hausman test proposed by Hausman (1978) were adopted. For related test models, refer to Huang (2005).

\section{The ANALYS IS OF EMPIRICAL F INDINGS}

\subsection{Data sources and quantitative analysis of descriptive statistics}

The data used in this paper covered different industries from 1990 to 2014, a total of 25 years with 825 counts of data. The industry category is based on the classification of the Taiwan Stock Exchange Corporation: Cement, food, plastics, textiles and fibers, electrical engineering and machinery, electric cables, glass and ceramics, paper manufacturing, iron and steel, rubber, automobiles, construction and materials, transportation, tourism, finance and banking, trading and department stores, others, chemical engineering, biotechnology and medical, petroleum and utilities, semiconductors, computers and peripherals, optoelectronics, communications and internet, electronic parts and components, electronics channeling, information service, other electronics, stock management, and industry sector. In addition, but also distinguish to the four strategic industries of DRAM, LED, LCD, and photovoltaic energy. There are 33 categories.

In this paper, the loan concentration of individual industries will be found out on the basis of the defin ition stated in (2). The annual average of respective years will be shown in Table 1, the quantitative analysis of the descriptive statistics of the loan concentration of individual industries and ranked by the order of mean values. ${ }^{2}$ From Table 1, we can see that the finance and banking industry ranked at the top. This could be the result of call loans among the banks. It was followed by transportation, tourism, and the iron and steel industries. Yet, no crisis has ever occurred in these industries. The last four rows in the tables, which are DRAM, LED, LCD and photovoltaic energy were tidied up by their loan concentration. The ranking of loan concentration in these four industries are not the highest among other industries. However, an insolvency crisis has occurred in these industries such that the annual increase

${ }^{2}$ DRAM, LED, LCD and photovoltaic energy are not the industries listed in TWSE. As such, they are not included in Table 1. 
American Research Journal of Business and Management, Volume 1, Issue 3, 2015

ISSN 2379-1047

of loan concentration in these industries has attracted the utmost attention. From the loan concentration ratio and the distribution of long-term and short-term loans as shown in Figure 1 to Figure 4, we could see that loan concentration in the DRAM industry substantially moved up annually since 2004. Loan concentration in the LCD industry also moved up annually since 1998. In the LED industry, it displayed the trend of annual increases at the beginning but fell since 2003, and then moved up again at significant levels from 2007 onward. For the photovoltaic energy industry, loan concentration moved up substantially since 2005. As such, we could see that loan concentration in these four industries tended to move up consistently since the financial cris is in 2007. This result is congruent with the government effort in offering financial relief for these industries.

Table 1.Basic descriptions of different industries loan concentration (1990 2014)

\begin{tabular}{|c|c|c|c|c|c|c|}
\hline Industries & Mean & $\min$ & $\max$ & Kurtotis & skewness & ranking \\
\hline Finance & 0.1841 & 0.1097 & 0.2485 & -0.1423 & 2.9677 & 1 \\
\hline Shipping and Transportation & 0.1153 & 0.0819 & 0.1623 & -0.4264 & 1.5601 & 2 \\
\hline Tourism & 0.1203 & 0.0819 & 0.1483 & -0.4369 & 1.5264 & 3 \\
\hline Semiconductor & 0.0768 & 0.0189 & 0.1160 & -0.6201 & 1.7385 & 4 \\
\hline Iron and Steel & 0.0739 & 0.0365 & 0.1187 & 0.4325 & 1.6653 & 5 \\
\hline Plastic & 0.0689 & 0.0448 & 0.0953 & 0.5679 & 2.05651 & 6 \\
\hline Textile & 0.0636 & 0.0255 & 0.1195 & 0.0952 & 3.51694 & 7 \\
\hline Building Material and Construction & 0.0678 & 0.0371 & 0.0964 & 0.0451 & 1.2841 & 8 \\
\hline Optoelectronic $\quad$ Industry & 0.0642 & 0.0084 & 0.1343 & 0.3742 & 1.3682 & 9 \\
\hline Others & 0.0389 & 0.0186 & 0.0519 & -0.3182 & 1.8972 & 10 \\
\hline Oil, Gas and Electricity & 0.0293 & 0.0021 & 0.0592 & -0.3456 & 1.5171 & 11 \\
\hline Computer and Peripheral Equ ip ment & 0.0249 & 0.0111 & 0.0482 & 0.3989 & 2.7912 & 12 \\
\hline Other Electronic & 0.0273 & 0.0150 & 0.0429 & 0.6582 & 2.8639 & 13 \\
\hline Electronic Parts/Components & 0.0292 & 0.0072 & 0.0347 & -0.1926 & 1.5671 & 14 \\
\hline Electronic and Machinery & 0.0191 & 0.0132 & 0.0226 & 0.0944 & 1.6361 & 15 \\
\hline Electronic and Cable & 0.0179 & 0.0080 & 0.0329 & 0.6062 & 2.7633 & 16 \\
\hline Cement and Ceramic & 0.0172 & 0.0090 & 0.0232 & -0.2789 & 1.6680 & 17 \\
\hline Food & 0.0163 & 0.0094 & 0.0311 & 1.3235 & 4.1483 & 18 \\
\hline Trading and Consumer's Goods & 0.0141 & 0.0089 & 0.0213 & 0.6203 & 2.2552 & 19 \\
\hline Paper and Pulp & 0.0142 & 0.0045 & 0.0378 & 1.0739 & 2.8893 & 20 \\
\hline Che mical & 0.0133 & 0.0072 & 0.0208 & 0.3588 & 2.1931 & 21 \\
\hline Communications and Internet & 0.0130 & 0.0018 & 0.0347 & 1.0091 & 3.2561 & 22 \\
\hline Automobile & 0.0103 & 0.0020 & 0.0242 & 0.9502 & 2.4269 & 23 \\
\hline Electronic Products and Distribution industry & 0.0084 & 0.0005 & 0.0124 & -0.2478 & 1.6963 & 24 \\
\hline Rubber & 0.0073 & 0.0040 & 0.0113 & 1.2262 & 4.7437 & 25 \\
\hline Management Stocks & 0.0051 & 0.4135 & 1.5994 & 0.0079 & 0.0027 & 26 \\
\hline Biotechnology and Medical Care & 0.00396 & 0.0023 & 0.0043 & -0.3748 & 2.9493 & 27 \\
\hline Information Service & 0.0019 & 0.0000 & 0.0040 & 0.1159 & 2.7622 & 28 \\
\hline Glass and Ceramic & 0.0018 & 0.0004 & 0.0038 & 0.6822 & 2.2206 & 29 \\
\hline DRAM & 0.0248 & 0.0028 & 0.0662 & 0.4732 & 2.2397 & \\
\hline LCD & 0.0502 & 0.0040 & 0.1206 & 0.4173 & 1.3701 & \\
\hline LED & 0.0045 & 0.0007 & 0.0087 & 0.4278 & 2.0783 & \\
\hline Solar & 0.0028 & $5.80 \mathrm{E}-05$ & 0.0135 & 1.9957 & 5.5405 & \\
\hline
\end{tabular}


American Research Journal of Business and Management, Volume 1, Issue 3, 2015 ISSN 2379-1047

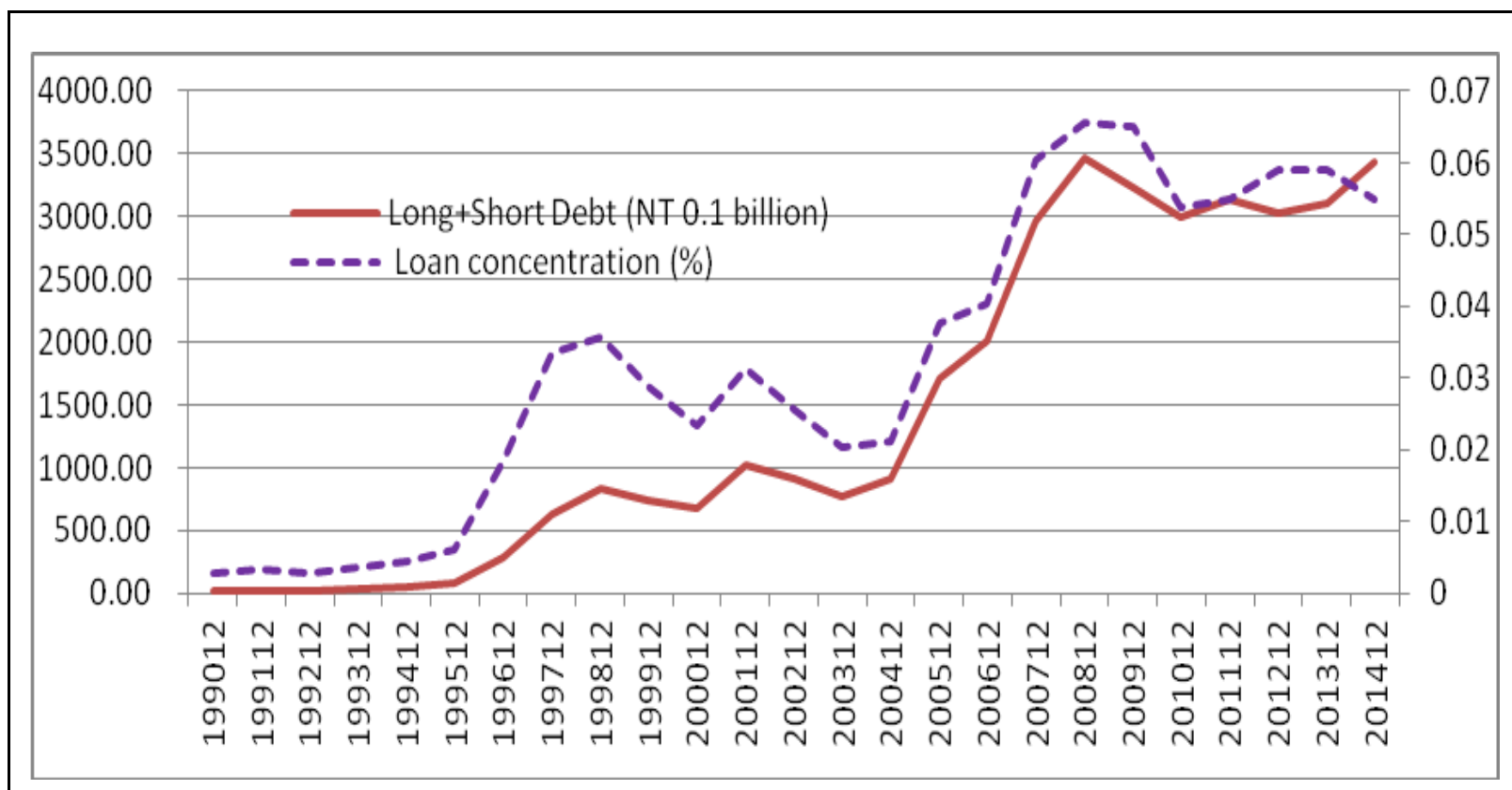

Figure1. Loan concentration of DRAM

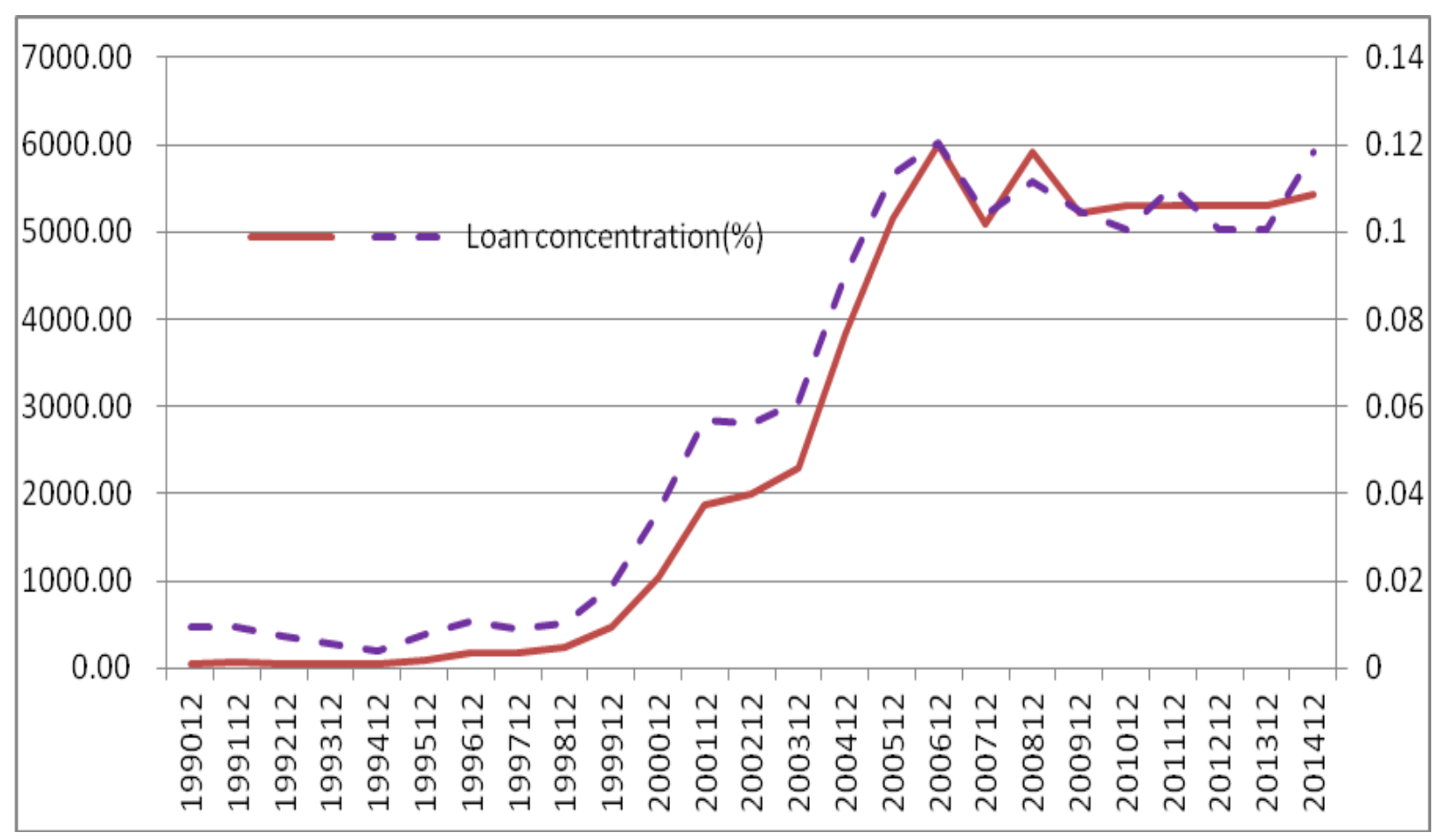

Figure2. Loan concentration of $L C D$ 
American Research Journal of Business and Management, Volume 1, Issue 3, 2015 ISSN 2379-1047

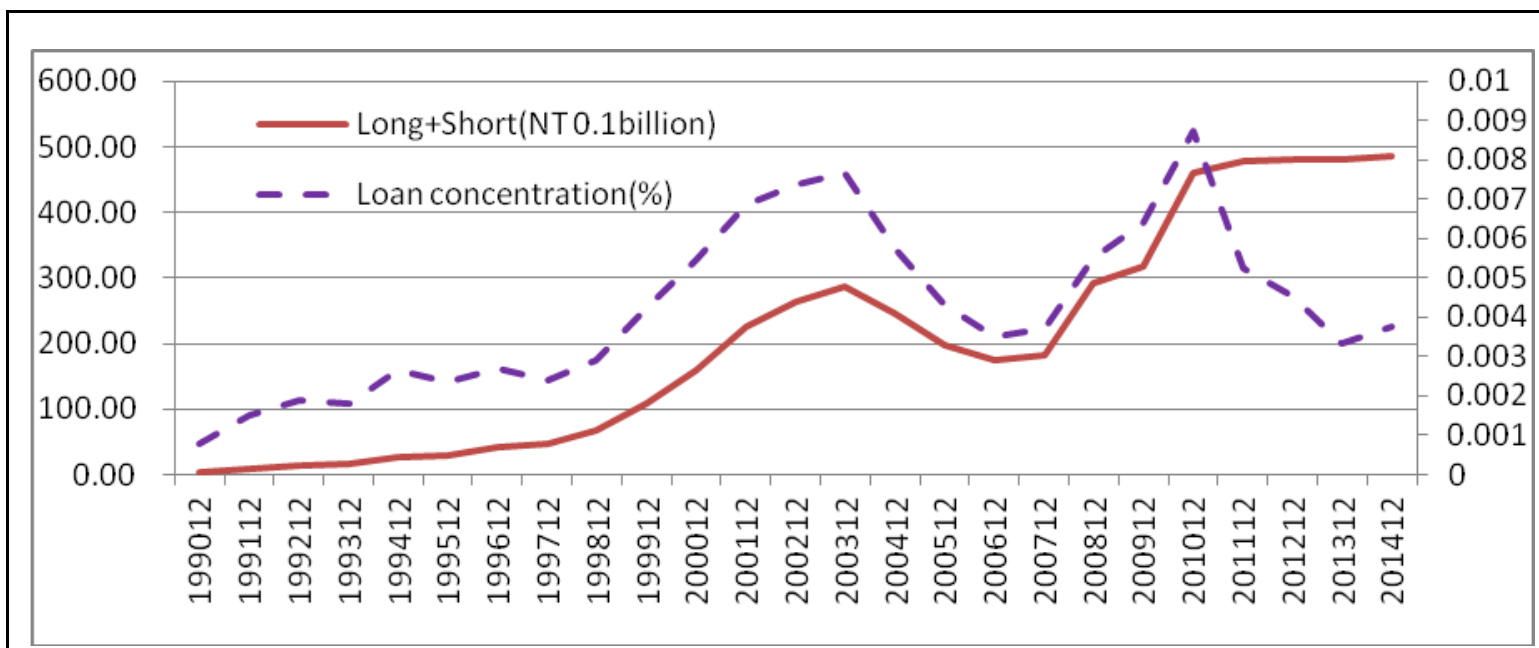

Figure3. Loanconcentration of LED

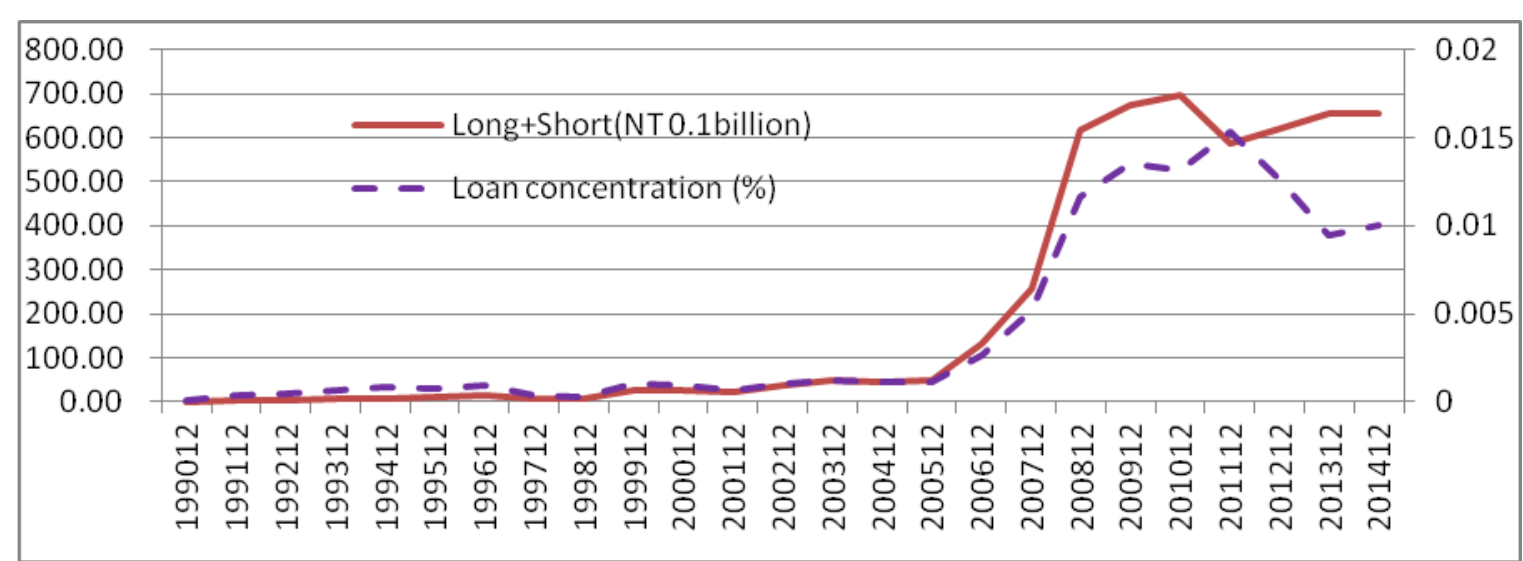

Figure4. Loan concentration of SOLAR

\subsection{An analysis of the four industries}

The electronics of Taiwan started to gain momentum since the 1970s. In the 1980s, a tremendous number of s mall and mediumelectronic enterprises were established under the assistance of the government, which made Taiwan the world supplier of electronic parts and components and an OEM service provider. In the 1990s, the huge demand for semiconductors substituted the traditional electronics industry. The application of semiconductors for smart computers became highly common and popular in the business and industrial sectors. The emergence of the Internet and the extensive use of the web in transactions in the 2000 s compelled the computer semiconductor sector to turn their attention to mobile personal devices and expand into that area. In the decade of 2000 to 2010 , the industry started to supply (1) corporate users - Internet server computers, internet printers, and HDD, and (2) personal users - PDAs (Personal Digital Assistants), smart phones, minicomputers, and touch screens, which drove the innovative changes in semiconductor parts, including CPUs (central processing units), GPU (Graphics Processing Unit), ROM (Read Only Memory), RAM (RandomAccess Memory), Monitor (Touch Screen 、Touch Pad) towards smart devices. The condensation of the production process of semiconductors aimed at streamlining the size of the parts and the fortification of the capacity in energy efficiency and performance for personal portable devices to make the these 
devices become smaller in size, slim, light, and streamlined. Competitive power in marketing determined the physical appearance and performance of products. The upgrade of equipment at the DRAM (Dynamic Random Access Memory) and LCD (Liguid Crystal Display) plants pushed up the fixed cost. As such, the upgrade of processes tended to be slowed and could not meet the demands and withstand the competition of the world semiconductor industry. Likewise, they could not develop their own brands and relied heavily on the OEM production of DRAM for the giant firms of USA and Japan. Furthermore, the technological-know-how of the industry also relied heavily on the licensing of RAM manufacturers in USA and Japan, and did not engage in any research and development of technologies, even with government assistance. They finally lost their edge in market and accumulated heavy losses. The following is an analysis of the four strategic industries one-by-one.

\subsubsection{The Dram Industry}

Computer memory is one of the four major categories of semiconductor products. Memory is used for the storage and release of data. DRAM is one kind. DRAM is marginally differentiated and is highly substituted. As such, firms have to make ceaseless investment to engage in technological research and development, capacity expansion, and the procurement of equipment. The life span of this product is getting shorter and shorter, and the price is keenly competitive.

The inputs of technology and capital determined the competitive power of the firms and hence their share in the market. This makes the DRAM industry capital-intensive and technology-intensive and entails high entry and exit barriers. In addition, the production technology of DRAM is monopolized in the hands of a few giant firms. For buttressing their competitive power, firms in the middle and lower segments of the industry tended to seek licensing or strategic alliances with the giant firms thereby inclined towards different technology camps. In Taiwan, DRAM firms tended to inclined towards two major camps, except Winbon Electronics, which has already pulled out from the market in standard DRAM. One of the technology camps is Micron Technology of USA, with Nan Ya Technology and Inotera Memories as the principal players. Another is Elpida Memory, Inc. of Japan, with ProMOS Technologies, Powerchip Technology and Rexchip Electronics (now acquired by Micron Technology) as the principal players. In light of the disequilibrium in supply and demand in the world market, the DRAM industry is now in recession. DRAM firms in Taiwan tended to seek transformation from producers of standard DRAM to special DRAM. However, the micro production process of these firms fell behind those of international giant firms, which put them in a subordinate position in market competition. Furthermore, the costs of production are also high. In general, the difficulties of DRAM in Taiwan are: (1) the lack of core technology; (2) licensing royalties are too high; (3) the lack of production process switching capacity. As of the end of January 2012, the balance of loans to the major DRAM firms of Taiwan ${ }^{3}$ was NT $\$ 211.8$ billion, which accounted for $0.97 \%$ of the balance of total loans of all do mestic banks of Taiwan. Public -owned banks accounted for $58.2 \%$ of the balance of loans.

\subsubsection{The screen industry}

Clouded by the pessimistic view towards global economic recovery, demand for consumer electronics worldwide turned sluggish. Despite the fact that screen manufacturers tended to cut down their production volume, they still have problems dealing with the excessive supply and declining prices in large-sized screens. International giant firms made great efforts to undergo transformation and downsize their scale of production through outsourcing for production with a view to resume the equilibriu m of supply and demand in the market worldwide.

Among all of the screen manufacturers in Taiwan, Chi Mei Electronics and AUO focused on the production of large and medium size screens while Chunghwa Picture Tubes (CPT) and HannSTar Display Corporation focused on the production of medium and small size screens. Screen manufacturers of Taiwan lack their own brands of terminal

\footnotetext{
${ }^{3}$ Major DRAM firms are ProMOS, Powerchip, Rexchip, W inbond, Nan Ya, and Inotera.
} 
products, and have been severely hampered by the debt crisis in the Euro Zone and the deferred demand for LCD TVs in Mainland China, which resulted in the decline in the utilization of production capacity to the extent that the price of large screens plummeted and profits similarly declined. As of the end of December 2011, the loan balance of the regional banks of Taiwan to the major screen manufacturers ${ }^{4}$ was NT $\$ 398.6$ billion, which accounted for $1.85 \%$ of the total loan balance of local banks in Taiwan and surpassed the aforementioned DRAM industry.

\section{THE LED (LIGHT EMITTING DIODE) INDUS TRY}

LED, or light emitting diode, is a kind of electronic component that gives out light when electricity passes through, and is manufactured using semiconductor materials, including the III-V group of chemical elements (e.g., GaN, GaP, and GaAs). The main feature of LED is: it is a kind of cold fluorescent light with life span of longer than 100,000 hours, no idling time, with rapid response (usually 9-10 seconds), small in size, energy saving, low pollution, and is suitable for mass production with high reliability. It can be manufactured to be very s mall or in components in a matrix form to fit different applications. This product is applicable to a wide array of purposes, including automobiles, the communications industry, computers, traffic signals, and monitors.

The production of LEDs world wide tended to be concentrated in a few Asian countries like Japan, Korea, and Taiwan. In 2010, the global production value of LED in Japan, Korea, and Taiwan together accounted for $74.5 \%$ of world production. If Mainland China was included, it would have made up to $82.8 \%$ of world total. In 2010, the production value of Japan accounted for $31.3 \%$ of the world and was the champion. It was followed by Korea, which accounted for $24.1 \%$, and Taiwan, which accounted for $19.1 \%$. In 2011, the production value of Mainland China and Korea started to climb and accounted for $9.0 \%$ and $25 \%$ respectively. In the same year, the production value of Japan, Europe, and USA fell to $30.5 \%, 6.5 \%$, and $9.8 \%$, respectively. The production value of Taiwan slightly grew to $19.2 \%$, but was behind Korea for two consecutive years. The major firms of Taiwan are Everlight Electronics, Epistar Corporation, Formosa Epitaxy, and Unity Opto Technology.

The LED industry of Taiwan is weak in patent and licensing and research and development, and also suffers from an inadequacy of technological-know-how capacity: die and encapsulation firms like Epistar and Everlight have made continued efforts in investment in the research and development of technology and also patenting as compared with the other major LED firms. However, Taiwan firms can only make their effort in process improvement and cost down with current level of technological-know-how and they have problems in long-term technology research and development and patent development. Everlight has launched products carrying its own brand with a view to upgrading its market share, but confronted law suits on patent infringement in Japan and other advanced nations. This indicated that Taiwan is in a disadvantageous position in long-term development and investment in the research and development of the industry.

\section{The Photovoltaic EnERgy Indus TRY}

The most important aspect of the photovoltaic energy industry is the photo Voltaic Cell or PV. This is a plate for absorbing solar energy. When solar energy passes through the atmosphere, it can generate 180 Watts of energy per square meter. PV can be used as a photovoltaic battery cell installed on the building of the households for the storage of photovoltaic energy (about 3kw/household), reg ional photovoltaic power plants, and other power storage cells. $\mathrm{PV}$ is an application of silicon crystal and could be extended and developed from semiconductor manufactories. This is an application of optoelectronics with solid state semiconductors for the conversion of energy storage and release. This is the mainstream power supply of the green energy industry of the future, and could be applied to buildings, automobiles, power plants, and different mobile devices, machinery, and components for the energy supply of optoelectronics (photovoltaic energy optoelectronic controller, photovoltaic motors, automobiles, and aviation). The conversion of photovoltaic energy to mechanical energy is a new revolution in its preliminary stages. It will be one of the-state-of-the-art products in the $21^{\text {st }}$ century.

The decreasing amount of subsidies from the governments of Europe triggered the rush for the installation of the

${ }^{4}$ Major screen manufacturers are Chi Mei, A UO, CHT and HannStar. 
device. It was coupled with the falling price of the photovoltaic energy system, to the extent that the demand for the installation of photovoltaic energy devices surged, which dictated capacity expansion in the manufacturing of photovoltaic energy devices. Since the supply of this kind of device moved up very quickly but the projected demand is on the decline, there was an oversupply of the product in the industry. Likewise, the price of PV quoted also fell significantly. Statistical figures showed that the total balance of loans from Bank of Taiwan to the solar energy sector ${ }^{5}$ amounted to NT\$59.1 billion (including overdue loans of NT \$315 million), which accounted for $0.27 \%$ of the total loan balance of all local banks of Taiwan. The scale of individuals firms is not comparable to the DRAM firms and the impact of this industry to the financial system of Taiwan is not significant.

In sum, we could see that the loan balance of the banks in Taiwan to the DRAM, screen, and photovoltaic energy industries accounted for $0.97 \%, 1.85 \%$, and $0.27 \%$ of the total balance of loans from all local banks of Taiwan, respectively. Respective creditor banks have already appropriated relevant provisions for doubtful accounts in accordance with the "Regulation Governing the Collection of Overdue Loans", and recognized additional provisions for bad debts for individual firms depending on the actual situation. As such, credit risk to the banks is marg inal. For assisting the banks to realize risk control as the foundation for lending, Financial Supervisory Commission of the ROC (Taiwan) has demanded all banks to set their debt coverage ratio to no less than $1 \%$.

\subsection{Analysis with the panel data regression model}

This paper is an attempt to further explore the effect of loan concentration on corporate operation performance. A panel data regression analysis has been conducted on individual industries as stated in Table 1. Performance of individual industries is evaluated by the Return of Assets, or ROA, and the explained variable is the revenue and loan concentration of individual enterprises.

Table 2 shows the results of different tests. From this table, we could see that LR rejects the null hypothesis in the test, which implies that the fixed effect model is suitable. From the test of LM, we could see that the random effect model is superior to the simple regression OLS model. Finally, the result of the Hausman test indicated that fixed effect model is the optimal choice. As such, this paper adopted the estimate and tests of the fixed effect model. Table 3 shows the result of the panel data regression analys is model. The coefficients for revenue and loan concentration are in negative values, implying that revenue and loan concentration negatively correlated with performance indicators at a significant level. The model determined that coefficient $\mathrm{R}^{2}$ is 0.4091 , imply ing that the variable of the model gives fairly good explanative power.

Table2. Results of panel data model selection

\begin{tabular}{|c|l|l|l|c|}
\hline \multicolumn{2}{|l|}{ dependent variable : ROA } & & & \\
\hline \multicolumn{2}{|c|}{ models } & \multicolumn{2}{|c|}{ statistics } & \multicolumn{2}{c|}{-value } \\
\hline \multirow{2}{*}{ LR Test } & $\mathrm{H}_{0}:$ OLS & F Statistic & $7.5237^{* * * *}$ & $<0.01$ \\
\cline { 2 - 5 } & $\mathrm{H}_{1}:$ Fixed Effect & Chi-Sq. Statistic & $304.3153^{* * *}$ & $<0.01$ \\
\hline \multirow{2}{*}{ LM Test } & $\mathrm{H}_{0}:$ OLS & & & $<0.01$ \\
\cline { 2 - 5 } & $\mathrm{H}_{1}:$ Random Effect & Chi-Sq. Statistic & $7.2094^{* * *}$ & \\
\hline \multirow{2}{*}{ Hausman Test } & $\mathrm{H}_{0}:$ Random & & & \\
\hline
\end{tabular}

Note: $* * *$ denotes significant at the $1 \%$ significance levels.

5 Manufacturers of photovoltaic cells are the makers of PV and other modules. They are classified by principal economic activities in proportion to their revenue where the firms with the highest score will be the benchmark for classification. There are 9 firms titled as PV manufacturers listed in TWSE/GTSM. 
American Research Journal of Business and Management, Volume 1, Issue 3, 2015

ISSN 2379-1047

Table3. Panel data analysis results(fixed effect model)

\begin{tabular}{|l|l|l|l|l|}
\hline & coefficient & s.d. & t-ratio & p-value \\
\hline constant & 0.1058 & 0.0031 & 34.1290 & $5.5175 \mathrm{e}-072^{* * *}$ \\
\hline revenue & $-1.1195 \mathrm{e}-06$ & $3.5682 \mathrm{e}-07$ & -3.1374 & $0.0015^{* * *}$ \\
\hline loan concentration & -0.2451 & 0.0217 & -11.2949 & $7.3813 \mathrm{e}-028^{* * *}$ \\
\hline Sum squared Error (SSE) & 0.7873 & S.E. of regression & 0.0354 \\
\hline \multicolumn{2}{|l|}{ R-squared } & 0.4091 & P-value(F) & $1.0453 \mathrm{e}-49^{* * *}$ \\
\hline
\end{tabular}

Note.1. s.d. is standard deviation. 2.*** denotes significant at the $1 \%$ significance levels.

\section{Conclusion}

As aforementioned, loan concentration is an essential indicator for banks and enterprises. In this paper, the loan concentration of individual enterprises from the period of 1990 to 2014 was subject to analysis and ranking by order. The results showed the top five industries are finance and banking, transportation, tourism, semiconductors, and iron and steel. Yet, these industries saw no crises occurring. DRAM, LED, LCD and photovoltaic energy industries have been under the support of the government of Taiwan for years. Hampered by the changes in the international operation environment, they faced a crisis in their operations. The strong support of the government for financial relief resulted in the high loan concentration of banks to these industries, which in turn affected the operational performance and pushed up the non-performing rate. According to the data released by Financial Supervisory Commission of the ROC (Taiwan), the total loan balance of local banks a mounted to NT\$22,527. 8 billion as of the end of 2014 and the majority was long-term loans, followed by short-term loans, and discount, import and export negotiation, and overdue loans. Some of the loans are related to 3D1S.

In this paper, the panel data regression model is used to assess the effect of loan concentration on the business performance of enterprises. The result indicated that the fixed effect model is the most optimal choice. The empirical findings indicated that the coefficient of loan concentration is a negative value, implying that loan concentration negatively correlated with profit indicators at a significant level. Excessive loan concentration will certainly affect the business performance of enterprises and banks. Risk management should be implemented for prevention. Close attention to the issue is also required.

Finally, the analysis of the paper indicated that the 3D1S industries of Taiwan do face high stress from international competition. If the government of Taiwan just demands that the public-owned banks provide financial leverage as relief for these industries in crisis, the business performance of the banks will be hampered. As a policy recommendation, the government should be cautious in taking such measures. In the past, the government has made tremendous efforts to support the development of OEM production. The LED industry, which has a low entrance barrier in technology, will face operational risk during economic downturns. The government should encourage the firms to engage in technological research and development, construct a stable and positive business environment with proper preferential treatment in taxation, and develop their own brands. This is the only way to surpass the competition of low-profit OEM production.

\section{REFERENCES}

[1] Chuang, N. T. (2004). An Empirical Study of The Effects of Lending Band Loan Concentration, Taiwan National Kaohsiung First University and Technology. Financial Operations of the Master's Thesis.(in Chinese)

[2] Chen, H. Y. (2007). Credit Centralized Generation Mechanism, Herd Behavior, Risk Concentration. PCA-logit Risk Measure, Hohai University Doctoral Thesis (in-Chinese).

[3] Liou, X. H. (2004). The Study of Loan Concentration Effects on Syndicated Loan and Non-syndicated Loan Market after Financial Crisis, Department of International Trade Master's thesis, Chinese Culture University.(in-Chinese)

[4] Altunbas, Y.,Fazylov, O. \& Molyneux, P. (2002). Evidence on the Bank Lending Channel in Europe. Journal of Banking \& Finance, .26(11),2093-2110. 
[5] Ayuso, J., Pérez, D. \& Saurina, J.(2004). Are Capital Buffers Pro-cyclical? Evidence from Spanish Panel Data. Journal of Financial Intermediation, 3(2), 248-264.

[6] Breusch, T. S. \& Pagan,A. R. (1980). The Lagrange Multiplier Test and Its Applications to Model Specification in Econometrics. The Review of Economic Studies, 47, 239-254.

[7] Dullmann, K. \& Masschelein, N. (2006). Sector Concentration in Loan Portfolios and Economic Capital, Deutsche Bundesbank. Discussion Paper Series 2: Banking and Financial Studies, 2006,09

[8] Greene, W. H.(2003), Econometric Analy sis, 5th, Prentice Hall.

[9] Hausman, J. A.(1978). Specification Test in Econometrics. Econometrica, 46, 1251-1271.

[10] Henderson, B. \& Kaplan,S. E. (2000).An Examination of Audit Report Lag for Banks: A Panel Data Approach. Auditing : A Journal of Practice \& Theory,19(2),59-174.

[11] Jahn,N. , Memmel, C \& Pfingsten, A. (2013). Banks' Concentration versus Diversification in the Loan Portfolio, New Evidence from Germany. Discussion Paper. Deutsche Bundesbank No. 53

[12] Lee, H. N. (2010). Study on the Loans to the Same Borrower Concentration Risk Exposures of Large Commercial Banks, Shan xi University of Finance Master's Thesis.(in Chinese)

[13] Tabak ,B. M. , Fazio, D. M. \& Cajueiro, D. O.(2010). The Effects of Loan Portfolio Concentration on Brazilian Banks' Return and Risk, Working Papers Series 215 